\title{
Central Administration of a Growth Hormone (GH) Receptor mRNA Antisense Increases GH Pulsatility and Decreases Hypothalamic Somatostatin Expression in Rats
}

\author{
Elisabeth Pellegrini, ${ }^{1}$ Marie Thérèse Bluet-Pajot, ${ }^{1}$ Françoise Mounier, ${ }^{1}$ Pamela Bennett, ${ }^{2}$ Claude Kordon, ${ }^{1}$ \\ and Jacques Epelbaum 1 \\ 1 U159 Institut National de la Santé et de la Recherche Médicale, 75014 Paris, France, and 2Department of Medicine, \\ Bristol Royal Infirmary, Bristol BS28HW, United Kingdom
}

To test the hypothesis of the involvement of centrally expressed rat growth hormone receptors ( $\mathrm{rGH}-\mathrm{R}$ ) in the ultradian rhythmicity of pituitary GH secretion, adult male rats were submitted to a $60 \mathrm{hr}$ intracerebroventricular infusion of an antisense (AS) oligodeoxynucleotide (ODN) complementary to the sequence of rGH-R mRNA. Eight hour (10 A.M.-6 P.M.) GH secretory profiles, obtained from freely moving male rats infused with 2.0 $\mathrm{nmol} / \mathrm{hr}$ of $\mathrm{rGH}-\mathrm{R}$ AS, revealed a marked increase in $\mathrm{GH}$ peak amplitude (150 \pm 12 vs $101 \pm 10 \mathrm{ng} / \mathrm{ml})$, trough levels (16.2 \pm 3.0 vs $5.4 \pm 1.4 \mathrm{ng} / \mathrm{ml})$, and number of peaks $(2.9 \pm 0.3 \mathrm{vs}$ $1.8 \pm 0.2)$. No change was observed in rats treated with an ODN complementary to the prolactin receptor mRNA sequence $(2.0 \mathrm{nmol} / \mathrm{hr})$. Infusion of increasing ODN concentrations resulted in a dose-dependent stimulation of $\mathrm{GH}$ release. In par-

In the male rat, growth hormone $(\mathrm{GH})$ release displays a typical ultradian rhythm, with high amplitude GH secretory bursts occurring at 3.00-3.30 hr intervals throughout the nychthemeron (Tannenbaum and Martin, 1976). In addition to $\mathrm{GH}$ releasing hormone (GHRH) and somatostatin (SRIH), the two hypothalamic neurohormones controlling GH secretion, several other factors also participate in GH regulation (for review, see Bertherat et al., 1995). In particular, GH itself elicits a "short," hypothalamic, negative feedback on its own secretion. Intravenous (Willoughby et al., 1980; Clark et al., 1988) and intracerebroventricular (Tannenbaum, 1980; Abe et al., 1983) administrations of human $\mathrm{GH}$ strongly decrease $\mathrm{GH}$ plasma levels, an effect that has been attributed to inhibition of GHRH synthesis (Chomczynski et al., 1988) and release (Clark et al., 1988), increase in SRIH neuronal activity (Rogers et al., 1988; Lanzi and Tannenbaum, 1992), or both (Miki et al., 1989). Sensitivity of both SRIH and GHRH neurons to GH feedback is also suggested by experiments on hypersomatotropinemic rats, because subcutaneous grafts of tumoral GH cells result in increased SRIH mRNA in the periventricular nucleus $(\mathrm{PeV})$ and decreased GHRH mRNA in the arcuate nucleus (ARC) (Bertherat et al., 1993).

Received Aug. 2, 1996; revised Sept. 25, 1996; accepted Sept. 27, 1996.

We are grateful to the National Hormone and Pituitary Program for providing hGH, oPRL, and rGH; to SC6 Institut National de la Santé et de la Recherche Médicale for photographic work; and to Drs. Gloria S. Tannenbaum and Paul Kelly for helpful discussions.

Correspondence should be addressed to Jacques Epelbaum, U159 Institut National de la Santé et de la Recherche Médicale, 2ter rue d'Alésia, 75014 Paris, France.

Copyright (C) 1996 Society for Neuroscience $0270-6474 / 96 / 168140-09 \$ 05.00 / 0$ allel, somatogenic binding sites in the choroid plexus were decreased by $40 \%$, and levels of rGH-R mRNA were increased in the periventricular nucleus (PeV) but unchanged in the arcuate nucleus (ARC). Levels of somatostatin mRNA, in the PeV but not in the ARC, were lowered by the treatment. Levels of $\mathrm{GH}$-releasing hormone mRNA in the ARC were not affected. These data suggest that $\mathrm{GH}$ negative feedback results from a direct effect on central $\mathrm{GH}$ receptors and a subsequent activation of hypophysiotropic somatostatin neurons located in the anterior periventricular hypothalamus.

Key words: antisense oligonucleotides; growth hormone receptor; growth hormone pulsatility; somatostatin; growth hormone releasing hormone; in situ hybridization; male rat

Mechanisms involved in these $\mathrm{GH}$ effects are not completely elucidated as yet. Nevertheless, recent data indicate that the $\mathrm{GH}$ receptor gene is expressed in the rat hypothalamus (Hasegawa et al., 1993), and GH receptor mRNA-containing cells have been visualized in the $\mathrm{PeV}$ and the $\mathrm{ARC}$, the major respective locations of SRIH and GHRH neurons (Burton et al., 1992; Minami et al., 1993; Burton et al., 1995). A comparable distribution has also been reported on the basis of immunohistochemical studies (Lobie et al., 1993).

These anatomical observations, however, are not sufficient to demonstrate that hypothalamic $\mathrm{GH}$ receptors actually mediate the feedback effects of the hormone. The capacity of GH to cross the blood-brain barrier is not well validated, and several actions of the hormone are relayed by other moieties, such as the insulin-like growth factors (IGFs). In the present work, we examined whether centrally located $\mathrm{GH}$ receptors are involved in the ultradian rhythmicity of pituitary $\mathrm{GH}$ secretion. For that purpose, we attempted to block GH receptor synthesis in the CNS by infusing intracerebroventricularly an antisense (AS) oligodeoxynucleotide (ODN) complementary to a portion of the coding sequence of the rat $\mathrm{GH}$ receptor (rGH-R) messenger ODN. GH secretory profiles were monitored in rats treated with the AS and compared with values obtained in control animals or in rats treated with an ODN directed against the prolactin receptor, a related yet distinct receptor species. In parallel, brain somatogenic and lactogenic binding sites were monitored by autoradiography and rGH-R, GHRH, and SRIH mRNA levels measured by semiquantitative in situ hybridization. 


\section{MATERIALS AND METHODS}

\section{$A S O D N S$}

Eighteen base AS ODNs were synthesized. They correspond to the sequence overlapping the initiation codon of the rGH-R mRNA (rGH-R AS ODN: 5'-CAC-CCG-CCA-AAG-ATC-CAT-3') and of the rat PRL receptor (rPRL-R) mRNA (rPRL-R AS ODN: 5'-AGC-AAG-TGCAGA-TGG-CAT-3'), respectively (Genosys). AS ODNs were dissolved in saline and infused into the animals as described below.

\section{Animals}

Four weeks before the experiments, adult male Wistar rats weighing 100-150 gm (Charles River, St. Albin les Elbeuf, France) were housed individually in a room with controlled temperature $\left(22-24^{\circ} \mathrm{C}\right)$ and illumination (12 hr light/dark schedule with lights on at 1 A.M.). They had free access to food and water. Rats were handled regularly to minimize stress effects.

\section{Surgery procedures and blood sampling}

Nine days before the experiment, a chronic intracerebroventricular (ICV) cannula (Alzet, Brain Infusion Kit; Alza, Palo Alto, CA) was inserted into the lateral ventricle of the brain under pentobarbital anesthesia (35 mg/kg body weight, i.p.). The ICV cannula was stereotaxically positioned in the lateral ventricle according to the atlas of Paxinos and Watson (1986) at the following coordinates: anterior, -0.8 $\mathrm{mm}$ to the Bregma; lateral, $-1.5 \mathrm{~mm}$ to the midline; ventral, $-3.8 \mathrm{~mm}$ to the Bregma, with the incisor bar set at $-3.3 \mathrm{~mm}$ below the interaural line. The cannula was secured to the skull of the animal with stainless steel screws and dental cement. The ICV cannula was connected to a miniosmotic pump (Alzet 2002; Alza) by means of a polyethylene tube catheter, which was introduced under the dorsal skin of the animal. The flow moderator of the pump (delivery rate of $0.5 \mu \mathrm{l} / \mathrm{hr}$ ) was connected with the polyethylene catheter containing $85 \mu \mathrm{l}$ of saline, which was administrated for $7 \mathrm{~d}$. A small air bubble was inserted to separate this saline solution from an additional $30 \mu \mathrm{l}$ of saline or ASs at the required concentrations, to be delivered for an additional $60 \mathrm{hr}$ ( $48 \mathrm{hr}$ before and $12 \mathrm{hr}$ during the entire GH sampling period). A control group, consisting of rats that were anesthetized but not implanted with chronic ICV cannula, was also included in all experiments. After surgery, animals were allowed to recover in individual chambers.

GH sampling experiments were performed on freely moving rats. Two days before the experiments, an indwelling cannula was inserted into the right atrium under ether anesthesia as described previously (Bluet-Pajot et al., 1986). The cannula was filled with a $250 \mathrm{IU} / \mathrm{ml}$ heparinized physiological solution, and the animals were returned to their individual cages. On the day of the experiments, $2 \mathrm{hr}$ before the sampling period, the distal extremity of the cannula was connected to a polyethylene catheter filled with $25 \mathrm{IU} / \mathrm{ml}$ heparinized saline. Blood samples $(0.5 \mathrm{ml})$ were taken every $20 \mathrm{~min}$, from 10 A.M. to 6 P.M. After each sample, red blood cells were centrifuged, resuspended in saline, and reinjected at the next sampling to attenuate hemodynamic modifications. Plasma was stored at $-20^{\circ} \mathrm{C}$ until $\mathrm{GH}$ radioimmunoassay (RIA).

At the end of the experiments, the animals were killed, and brains were removed, frozen in isopentane $\left(-40^{\circ} \mathrm{C}\right)$ for $30 \mathrm{sec}$, and kept at $-80^{\circ} \mathrm{C}$. For autoradiography and in situ hybridization, serial $14 \mu \mathrm{m}$ cryostat sections at the level of the PeV from interaural 7.70 to 6.70 , according to the atlas of Paxinos and Watson (1986), and the ARC from interaural 6.44 to 5.40, according to the atlas of Paxinos and Watson (1986), were mounted on $2 \%$ gelatin-subbed slides and stored at $-20^{\circ} \mathrm{C}$ until use. Microscopic examination of toluidine blue-stained sections allowed for an appropriate anatomical match across animals and groups.

\section{GH receptor autoradiography}

Autoradiography was carried out as described previously (Bick et al., 1989). Tissue sections were preincubated in cold $25 \mathrm{~mm}$ Tris- $\mathrm{HCl}$ buffer, $\mathrm{pH} 7.4$, containing $10 \mathrm{~mm} \mathrm{MgCl}_{2}$ and $1 \% \mathrm{BSA}(\mathrm{w} / \mathrm{v})$ for $30 \mathrm{~min}$ and then incubated with the radiolabeled ligand $\left(2 \mathrm{nM}\left[{ }^{125} \mathrm{I}\right] \mathrm{hGH}\right.$; specific activity $78 \mu \mathrm{Ci} / \mu \mathrm{g}$; purchased from Dupont NEN, Les Ulis, France) in the above buffer for $18 \mathrm{hr}$ at $4^{\circ} \mathrm{C}$. Nonspecific binding and specific binding of somatogenic and lactogenic receptors were assessed, respectively, by coincubation of tissue sections with the same concentration of radiolabeled ligand plus a 500-fold excess of unlabeled hGH, $\mathrm{rGH}$, or oPRL. After incubation, the tissue sections were rinsed twice with cold buffer and twice with distilled water, dried, and tightly juxtaposed to tritium-sensitive films (Hyperfilm ${ }^{3} \mathrm{H}$, Amersham, Buckinghamshire, UK) for $72 \mathrm{hr}$ at $-20^{\circ} \mathrm{C}$; films then were developed in Dektol (Kodak, Marnes la Vallée, France). Binding was quantitated in disintegrations per minute/surface unit by reference to iodinated standards prepared from brain paste with the help of a computer-assisted image analyzer using a video camera and the RAG program (Biocom, Les Ulis, France), which allows for the conversion of optical densities into radioactivity units.

\section{In situ hybridization}

SRIH, GHRH. In situ hybridization was carried out as described elsewhere (Bertherat et al., 1993). Briefly, a 45-base oligoprobe (corresponding to amino acid $96-111$ of the prepro-SRIH cDNA) (Genofit, Geneva, Switzerland) was $3^{\prime}$-labeled with $\alpha^{35}$ S-dATP (Amersham) using terminal deoxynucleotidyl transferase (Boehringer Mannheim, Meylan, France) at a specific activity of $2000 \mathrm{Ci} / \mathrm{mm}$. Sections were fixed for $10 \mathrm{~min}$ at room temperature in potassium phosphate buffer containing $4 \%$ paraformaldehyde. Then they were prehybridized for 30 min in a solution containing $4 \times$ SSC and $1 \times$ Denhardt's solution (Sigma, Saint-Quentin Fallavier, France) and for $10 \mathrm{~min}$ in $4 \times$ SSC containing triethanolamine $(1.33 \%)$ and anhydrous acetic acid $(0.25 \%), \mathrm{pH} 8.0$. Hybridization was run for $18 \mathrm{hr}$ at $38^{\circ} \mathrm{C}$ in the hybridization solution $(50 \%$ formamide, $4 \times$ SSC, $1 \times$ Denhardt's, $1 \%$ sarcosyl, $10 \mathrm{~mm}$ dithiothreitol, $100 \mathrm{~mm}$ potassium phosphate, $\mathrm{pH} 7.4$, and $100 \mathrm{ng}$ of yeast tRNA and $100 \mathrm{ng}$ of herring sperm DNA) containing the labeled oligoprobe $(2 \mathrm{nM})$. Sections were rinsed at $36^{\circ} \mathrm{C}$ for $30 \mathrm{~min}$ in $4 \times \mathrm{SSC}, 3 \times 15 \mathrm{~min}$ in $1 \times \mathrm{SSC}$, and $3 \times 15 \mathrm{~min}$ in $0.1 \times$ SSC, dried, and coated by dipping in RPN40 LM1 emulsion (Amersham). Exposure time was 7 and $20 \mathrm{~d}$ at $4^{\circ} \mathrm{C}$ for the detection of SRIH mRNA in the PeV and ARC, respectively. Autoradiograms were developed in Dektol (Kodak), stained with toluidine blue, and coverslipped.

A similar method was used for GHRH mRNA hybridization in the ARC (Bertherat et al., 1993). Briefly, a 45-base oligoprobe (base 31-75 of the rat GHRH cDNA) provided by Genset (Strasbourg, France) was $3^{\prime}$-labeled with $\alpha^{33} \mathrm{P}$-dATP (Amersham). The hybridization was carried out at $36^{\circ} \mathrm{C}$, and sections were rinsed at $34^{\circ} \mathrm{C}$. Exposure time of the dipped slides was $6-8$ weeks.

$r G H$ receptor. A cDNA clone, pGO.9, containing the 900-base pair $\mathrm{bg} / \mathrm{II}$ fragment of the rat GH receptor cDNA cloned into the BamHI site of the vector pT7T318U, was kindly provided by Professor G. Norstedt (Huddinge, Sweden). The AS cRNA probe and the sense cRNA probe were synthesized in vitro with T7 polymerase on a plasmid linearized with $X b a \mathrm{I}$ and with T3 polymerase on plasmid linearized with SpeI, respectively. The radiolabeled cRNA was synthesized in vitro with $\alpha^{35} \mathrm{~S}$-UTP (Amersham) at a concentration of $5 \mathrm{~mm}$. The template DNA was removed by DNaseI treatment, and the radiolabeled riboprobe was separated from unreacted components by phenol-chloroform-isoamyl alcohol extraction. The riboprobe was then hydrolyzed with sodium hydrogen carbonate $\left(0.4 \mathrm{M} \mathrm{NaHCO}_{3}\right)$ to obtain fragments of $\sim 200$ bases in length.

Sections of the $\mathrm{PeV}$ and $\mathrm{ARC}$ region were dried for $10 \mathrm{~min}$ at room temperature and fixed in $4 \%$ paraformaldehyde. Sections were rinsed in PBS and treated in a triethanolamine (1.4\%) and acetic anhydride $(0.25 \%)$ solution. Slides were dehydrated in a series of alcohols, delipidated in chloroform, and dried. The riboprobe was dissolved in hybridization buffer (25 mM Tris, pH 7.4, $1 \mathrm{~mm}$ EDTA, $350 \mathrm{~mm} \mathrm{NaCl}, 60 \%$ deionized formamide, $12 \%$ dextran sulfate, $50 \times$ Denhardt's, $5 \mathrm{mg}$ of yeast tRNA, $5 \mathrm{mg}$ of single-stranded salmon sperm DNA, and $125 \mathrm{~nm}$ dithiothreitol).

The rGH-R cRNA probe in hybridization buffer was positioned on each of the sections, which were glass-covered, sealed with rubber cement, and incubated overnight at $50^{\circ} \mathrm{C}$ in a humidified chamber. After hybridization, coverslips were lifted off gently in $2 \times \mathrm{SSC}$ at room temperature, and the slides were washed for $30 \mathrm{~min}$ in two changes of $2 \times$ $\mathrm{SSC} / 50 \%$ formamide at $50^{\circ} \mathrm{C}$. Sections were then rinsed briefly in $2 \times \mathrm{SSC}$ at $37^{\circ} \mathrm{C}$ and incubated in $2 \times \mathrm{SSC}$ containing $20 \mu \mathrm{g} / \mathrm{ml}$ RNaseA for $30 \mathrm{~min}$ at $37^{\circ} \mathrm{C}$. Sections were rinsed again in $2 \times \mathrm{SSC}$ and then washed in $3 \times 15$ min changes of $2 \times \mathrm{SSC} / 50 \%$ formamide at $50^{\circ} \mathrm{C}$, followed by two room temperature washes in $2 \times$ SSC for 5 min each. Slides were dipped briefly in water and then air-dried. The dried sections were dipped in RPN 40 LM1 emulsion (Amersham). Exposure time was 3 weeks.

Image analysis and quantification. Sections were visualized at $500 \times$ magnification (Leitz Orthoplan) under fluorescent epi-illumination. Grain counting was performed with a Biocom 200 image analyzer (Bio- 

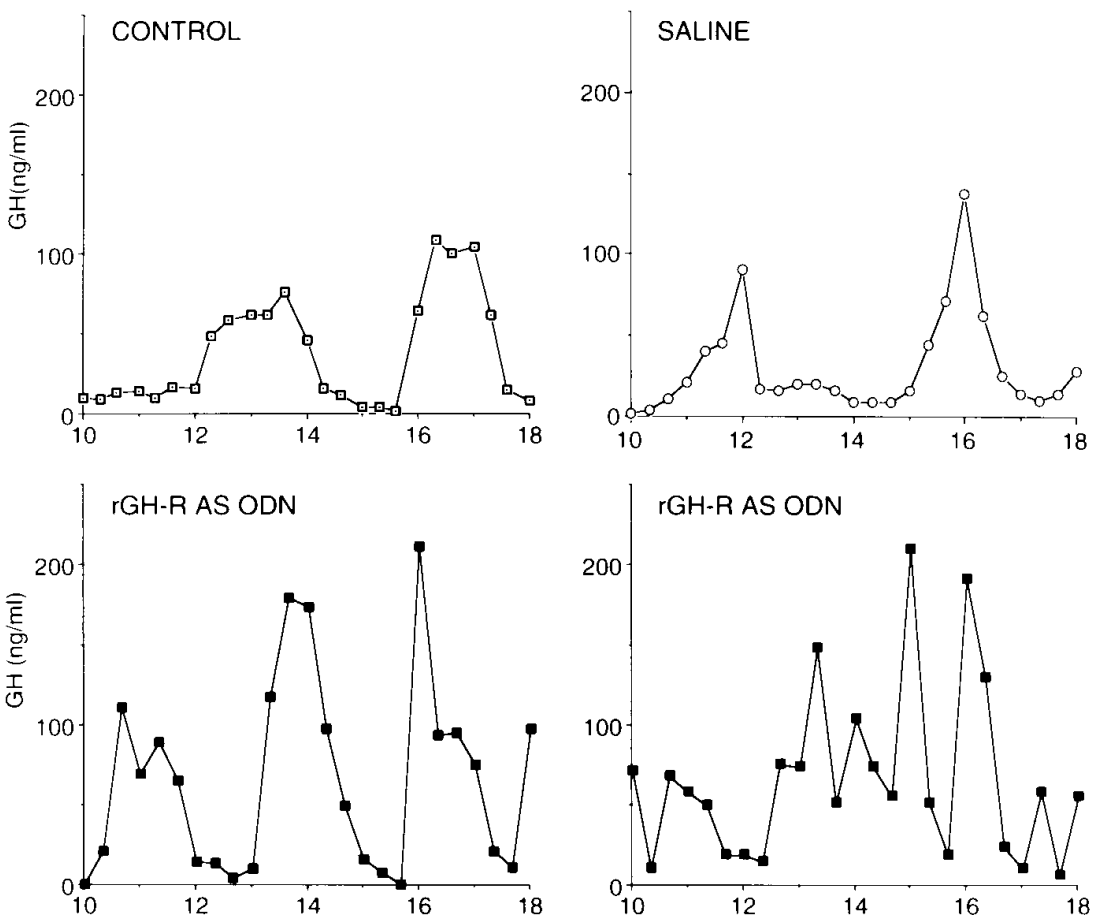

Figure 1. Representative rGH secretory patterns during an $8 \mathrm{hr}$ sampling period in control and saline-infused rats (top panels), and $r G H-R A S O D N\left(2.0 \mathrm{nmol} \cdot 0.5 \mu \mathrm{l}^{-1}\right.$. $\mathrm{hr}^{-1}$ )-treated (middle panels) and rPRL-R AS ODN (2.0 $\mathrm{nmol} \cdot 0.5 \mu \mathrm{l}^{-1} \cdot \mathrm{hr}^{-1}$ )-treated animals (bottom panels).
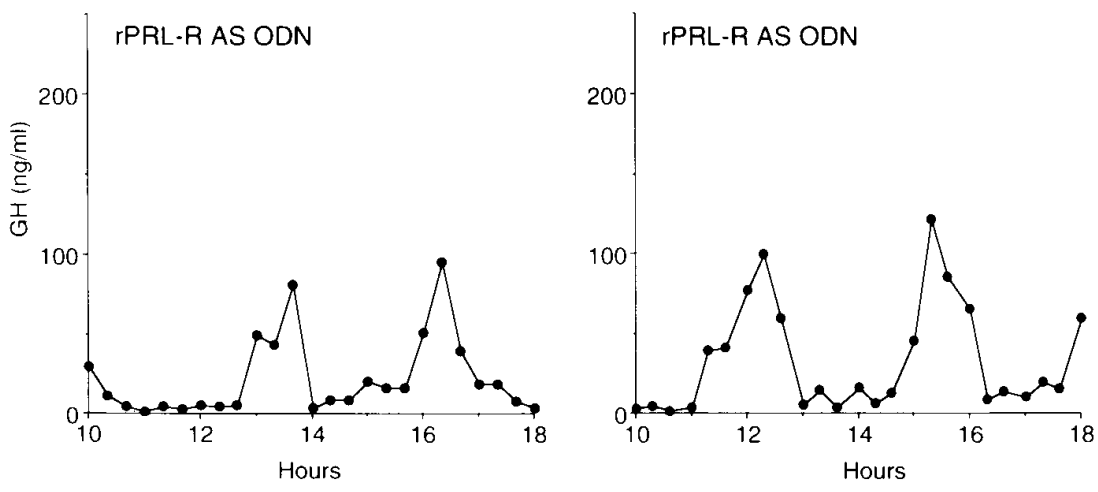

com, Les Ulis, France) using the computer-based image analysis system (RAG 200), which allows for rapid estimation of grain numbers over neuronal perikarya. An internal calibration curve was recorded for each section and measured the mean quantity of light reflected by a known number of grains according to the procedure described by Bisconte et al. (1968). Labeled neurons were identified by toluidine blue under brightfield illumination, delineated on the screen, and the quantity of light reflected in the area was measured under epi-illumination.

Eight sections per region $(\mathrm{PeV}, \mathrm{ARC})$ in each rat were analyzed for SRIH and GHRH mRNA in situ hybridization. Four sections corresponding to the level of the PeV and ARC were analyzed in each rat for the rGH-R mRNA in situ hybridization experiment.

\section{GH RIA}

Plasma GH concentrations were measured by RIA using materials supplied by the National Institute of Diabetes and Digestive and Kidney Diseases, as described previously (Bluet-Pajot et al., 1978). GH values are reported in terms of rGH-RP2. The sensitivity of the RIA is $1 \mathrm{ng} / \mathrm{ml}$. The intra- and interassay coefficients of variation are below $15 \%$.

\section{Statistical analysis}

$\mathrm{GH}$ pulse analysis was performed using the Cluster program (Veldhuis et al., 1987), with the $t$ value set to 4.1 to maintain false-positive rates under $1 \%$. Cluster size was set to one prepeak and one postpeak nadir value. False-positive error for peak detection was $7 \%$. Area under the curve (AUC) for GH response is calculated by means of trapezoidal analysis. Values are given as mean \pm SEM, and statistical analysis was performed by ANOVA using the statview 4.02 software (Abacus Concepts, Palo Alto, CA).

\section{RESULTS}

\section{Effect of AS infusions on GH secretion}

Implantation of a miniosmotic pump did not significantly alter body weight. The surgery caused a small, temporary weight loss, but treated animals had recovered their initial weight at the time of the experiment.

Administration of saline for nine consecutive days into the lateral ventricle did not affect the typical GH secretory pattern of normal rats (Fig. 1, top panels). By Cluster analysis, the number, amplitude, and interval between GH peaks, as well as nadir levels, were also the same in saline-infused and control animals (Table 1).

Administration of rGH-R AS ODN $\left(2.0 \mathrm{nmol} \cdot 0.5 \mu \mathrm{l}^{-1} \cdot \mathrm{hr}^{-1}\right)$ resulted in an increased overall secretion of GH (Fig. 1, middle panels), whereas in rPRL-R AS ODN-treated rats (Fig. 1, bottom panels) $\mathrm{GH}$ profiles were equivalent to those of control or salineinfused animals. By Cluster analysis (Table 1), both amplitude of GH peaks and nadir values were higher in rGH-R AS ODNtreated rats than in rPRL-R AS ODN-treated animals and saline- 


\begin{tabular}{|c|c|c|c|c|}
\hline & $\begin{array}{l}\text { Number of } \\
\text { peaks } / 8 \mathrm{hr}\end{array}$ & $\begin{array}{l}\text { Peak amplitude } \\
(\mathrm{ng} / \mathrm{ml})\end{array}$ & $\begin{array}{l}\text { Interval between } \\
\text { peaks (min) }\end{array}$ & $\begin{array}{l}\text { Nadir } \\
(\mathrm{ng} / \mathrm{ml})\end{array}$ \\
\hline Saline (5) & $1.8 \pm 0.2$ & $101 \pm 10$ & $200 \pm 11$ & $5.4 \pm 1.4$ \\
\hline rGH-R antisense ODN (12) & $2.9 \pm 0.3^{*}$ & $150 \pm 12^{* * *}$ & $118 \pm 9^{* * *}$ & $16.2 \pm 3.0^{* * *}$ \\
\hline rPRL-R antisense ODN (4) & $2.0 \pm 0.4$ & $92 \pm 5$ & $163 \pm 32$ & $5.0 \pm 1.5$ \\
\hline
\end{tabular}

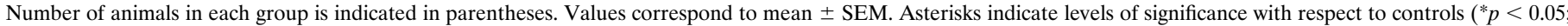
$* * * p<0.001)$.

infused animals. In rGH-R AS ODN-treated animals, peak number was increased, whereas the interval between peaks was decreased as compared with the three other groups.

When expressed as the total AUC (Fig. 2), the effect of rGH-R AS ODN treatment was dose-dependent and reached statistical significance for infusion rates of 1.0 and $2.0 \mathrm{nmol} \cdot 0.5 \mu \mathrm{l}^{-1} \cdot \mathrm{hr}^{-1}$. Infusion at the same maximal rate $\left(2.0 \mathrm{nmol} \cdot 0.5 \mu \mathrm{l}^{-1} \cdot \mathrm{hr}^{-1}\right)$ of rPRL-R AS ODN did not modify GH secretion.

\section{Effect of rGH-R AS ODN infusion on somatogenic and lactogenic binding sites}

Specific $\left[{ }^{125} \mathrm{I}\right] \mathrm{hGH}$ binding sites were visualized in the choroid plexus at the level of the dorsal part of the third ventricle and the lateral ventricle (Fig. 3). Somatogenic (i.e., rGH displaceable) binding sites accounted for $43 \%$ of $\mathrm{hGH}$ binding, and lactogenic (i.e., oPRL displaceable) binding sites accounted for $57 \%$ of total specific binding. After rGH-R AS ODN treatment, the density of the somatogenic binding sites was significantly decreased in the dorsal part of the third ventricle and the lateral ventricle as well. In contrast, the levels of the lactogenic binding sites remained unchanged. Measurable binding sites could not be quantified in the hypothalamus.

\section{Effect of rGH-R AS ODN infusion on rGH-R, SRIH, and GHRH mRNA levels in the hypothalamus}

In the hypothalamus, the distribution of rGH-R mRNAcontaining cells is illustrated in Figure 4 and compared with

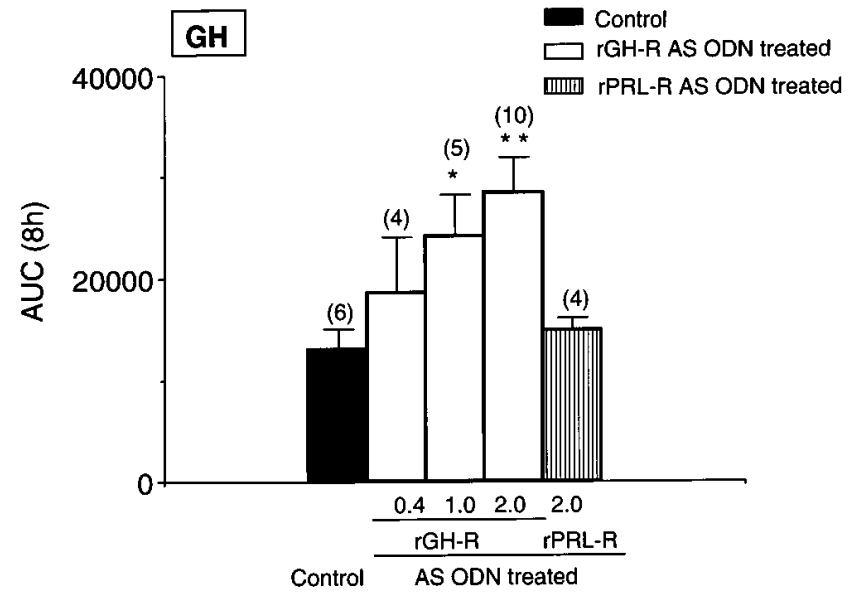

Figure 2. Effects of $r G H-R A S O D N\left(0.4,1.0\right.$, and $2.0 \mathrm{nmol} \cdot 0.5 \mu \mathrm{l}^{-1}$. $\left.\mathrm{hr}^{-1}\right)$ and $r P R L-R A S O D N\left(2.0 \mathrm{nmol} \cdot 0.5 \mu \mathrm{l}^{-1} \cdot \mathrm{hr}^{-1}\right)$ infusion on plasma $\mathrm{GH}$ levels. The number of animals for each experimental group is shown in parentheses over each bar. The AUC monitored throughout the recording period (10 A.M.-6 P.M.) is expressed as arbitrary units. Vertical lines represent SEM. Asterisks indicate the level of significance with respect to controls $\left({ }^{*} p<0.05 ;{ }^{* *} p<0.01\right)$. those of SRIH mRNA- and GHRH mRNA-containing cells. rGH-R mRNA-containing cells essentially were restricted to the PeV and the ARC. In the PeV, the distribution of rGH-R mRNA-containing cells was closely similar to that of SRIH mRNA-containing cells. In the ARC, rGH-R mRNA-labeled cells were distributed over the entire ventral portion of the nucleus, whereas GHRH mRNA cells were restricted to its ventrolateral part.

Infusion of rGH-R AS ODN did not modify the number of cells expressing rGH-R, SRIH, and GHRH mRNA (data not shown).

As visualized in Figure 5 (top panel) and quantified in Figure 6, rGH-R expression increased significantly in the $\mathrm{PeV}$ after infusion of rGH-R AS ODN. A weaker but not significant effect was also observed in the ARC. The increase in rGH-R mRNA was dependent on the concentration of the oligonucleotide (data not shown).

Infusion of rGH-R AS ODN reduced SRIH mRNA levels in the PeV (Figs. 5, bottom panel, and 7). In the ARC, SRIH expression was not affected significantly.

GHRH mRNA levels were not affected by AS infusion either in the ARC or around the ventromedial nuclei (Fig. 7,VMN).

\section{DISCUSSION}

Sixty-hour intracerebroventricular infusion of an AS ODN to the mRNA for rGH-R decreased somatogenic binding sites in the choroid plexus at the level of the dorsal part of the third ventricle and the lateral ventricle. In parallel, rGH-R mRNA levels were increased in the $\mathrm{PeV}$ but not in the ARC, suggesting some regional selectivity in translational arrest and ongoing transcriptional activity. In the same animals, AS treatment significantly increased pulsatile GH secretion and decreased SRIH mRNA levels in the PeV, without affecting GHRH mRNA levels in the ARC. These effects seemed specific and not caused by neuronal toxicity or general protein synthesis blockade, because infusion of an AS ODN to the mRNA for rPRL receptor, a protein closely related to the rGH-R, was without effect.

It was shown previously that in vivo application of AS ODN to neuropeptide receptor mRNAs such as neuropeptide $\mathrm{Y}$ (NPY)-Y1 (Wahlestedt et al., 1993b) and angiotensin AT1 receptors (Sakai et al., 1994) or neurotransmitter receptors such as the NMDA-R1 (Wahlestedt et al., 1993a) or the dopaminergic D2 receptor (Zhou et al., 1994) can diminish respective binding levels by $10-70 \%$. In the case of the $\mathrm{rGH}-\mathrm{R}$, it resulted in a $40 \%$ decrease in the somatogenic binding sites located in the choroid plexus visualized in the dorsal part of the third ventricle and the lateral ventricle, thus indicating that AS ODN treatment was effective. We were not able to detect reproducible $\mathrm{GH}$ binding in the hypothalamus of adult male rats by autoradiography, and others were also unsuccessful in adult female rats (Crumeyrolle- 
TOTAL BINDING

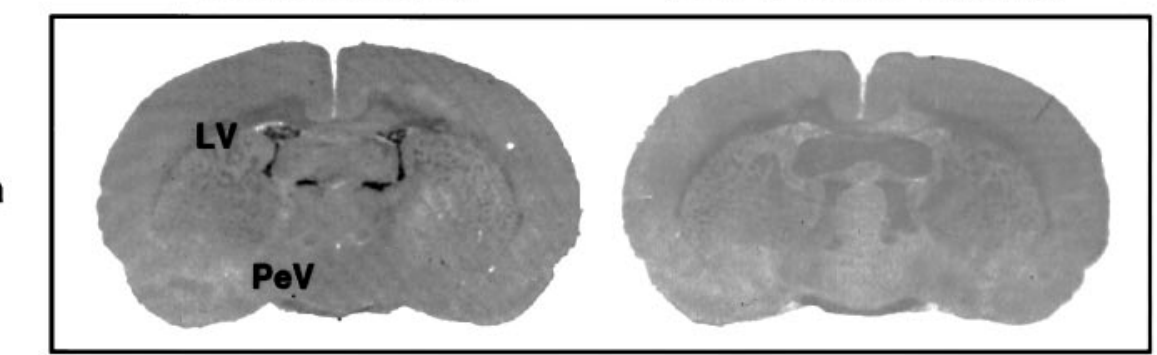

b

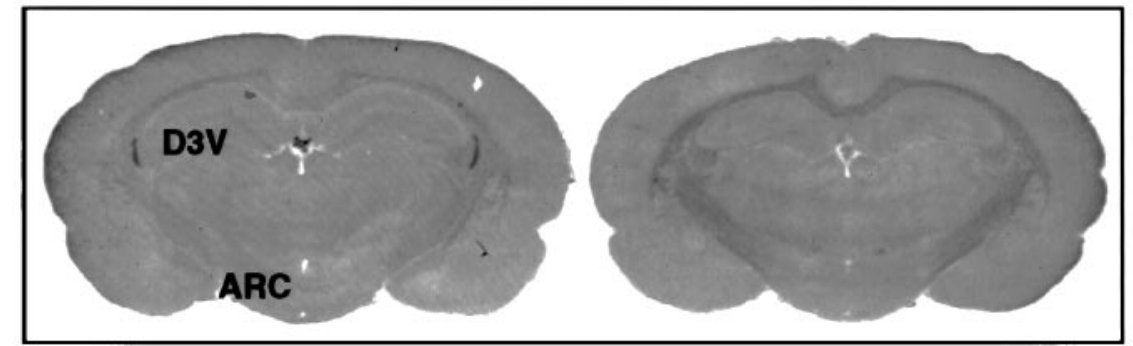

Figure 3. Effects of $r G H-R$ AS ODN $(2.0 \mathrm{nmol}$ $\left.0.5 \mu \mathrm{l}^{-1} \cdot \mathrm{hr}^{-1}\right)$ treatment on brain somatogenic (rGH-R) and lactogenic (oPRL-R) binding sites. $a$, Top left, Visualization of $\left[{ }^{125} \mathrm{I}\right] \mathrm{hGH}$ binding sites in the choroid plexus in the dorsal part of the third ventricle $(D 3 V)$ and the lateral ventricle $(L V)$ at the level of the periventricular hypothalamic nucleus $(\mathrm{PeV})$. Top right, Nonspecific binding in the presence of hGH $(1 \mu \mathrm{M}) . b$, Middle left, Visualization of $\left[{ }^{125} \mathrm{I}\right] \mathrm{hGH}$ binding sites in the choroid plexus in the $D 3 V$ and the $L V$ at the level of the arcuate nucleus $(A R C)$. Middle right, Nonspecific binding in the presence of hGH $(1 \mu \mathrm{M}) . c$, Bottom, Quantification of rGH-R and oPRL-R binding sites in control and rGH-R AS ODNtreated animals. Ten sections per region were analyzed in each rat; $n=6$ animals in each group. Data are expressed as mean \pm SEM, and asterisks indicate the level of significance as compared with controls $\left(* p<0.05 ;{ }^{* *} p<0.01\right)$.
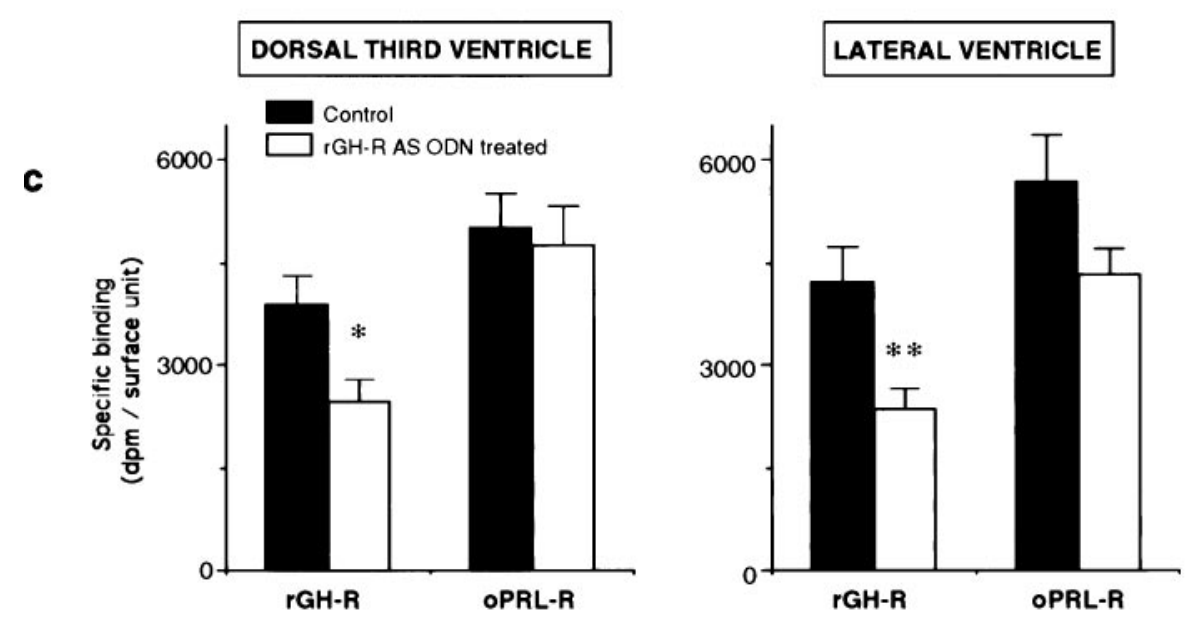

Arias et al., 1993). Indeed, the levels of GH-R immunoreactivity in the hypothalamus decrease considerably from the postnatal period to the adult stage (Lobie et al., 1993), whereas the expression of rGH-R mRNA remains measurable by Northern analysis (Hasegawa et al., 1993) and in situ hybridization (Burton et al., 1992; Minami et al., 1993). Thus, because of the very low levels of somatogenic binding sites in that region, we could not demonstrate directly that the AS treatment resulted in a decrease in $\mathrm{GH}$ binding levels in the hypothalamus. The increased concentrations of $\mathrm{rGH}$ receptor mRNA in the hypothalamic $\mathrm{PeV}$ after AS infusion, however, suggest that the ODN was effective in inhibiting translation, resulting in a compensatory increase in nontranslated mRNA. In a similar protocol, V1 receptor mRNA levels were also markedly increased locally after intraseptal infusion of AS oligonucleotides when compared with those of vehicle- or scrambled sequence-infused animals, and this resulted in a $60 \%$ decrease in V1 receptor binding (Landgraf et al., 1995). The effect of intracerebroventricular AS infusion on GH receptor mRNA levels was significantly more marked in the PeV than in the ARC, two major sites of rGH-R expression in the hypothalamus (Burton et al., 1992; Minami et al., 1993; Burton et al., 1995). We cannot exclude the possibility that diffusion of the ODN from the ventricle to the ARC is different than to the $\mathrm{PeV}$, because of the presence of specialized ependymocytes such as the tanycytes.
ICV administration of rGH-R but not rPRL-R AS ODN induced important modifications in spontaneous $\mathrm{GH}$ secretion of freely moving rats. All parameters of endogenous $\mathrm{GH}$ pulsatility were either increased (i.e., nadir, amplitude, and number of peaks) or decreased (interval between peaks) by treatment with rGH-R AS ODN. This observation confirms the existence of a short negative feedback of $\mathrm{GH}$ on its own secretion. In addition, it indicates that the hormone itself, not a distinct $\mathrm{GH}$-induced factor such as IGF, is responsible for the effect by acting on central GH receptors. It is noteworthy that this negative feedback affects not only peak amplitudes but also pulse frequency and nadir values.

In parallel, the AS ODN treatment resulted in decreased SRIH mRNA levels in the PeV and to a lesser extent in the ARC. It might be postulated simply that PeV but not ARC SRIH neurons are endowed with $\mathrm{rGH}$ receptors. Alternatively, this regional difference might be accounted for by less efficient diffusion in the ARC as argued above, and also by the fact that SRIH gene expression is much higher in the $\mathrm{PeV}$, the major hypothalamic source of SRIH, than in the ARC. The fact that SRIH mRNA levels in the PeV are decreased in rGH-R AS ODN-treated animals, in which high GH levels are recorded, is also a good index of the blockade of the GH feedback induced by the AS treatment, because experimental hypersomatotropinemia usually 
rGH-R mRNA

\section{Periventricular nucleus}
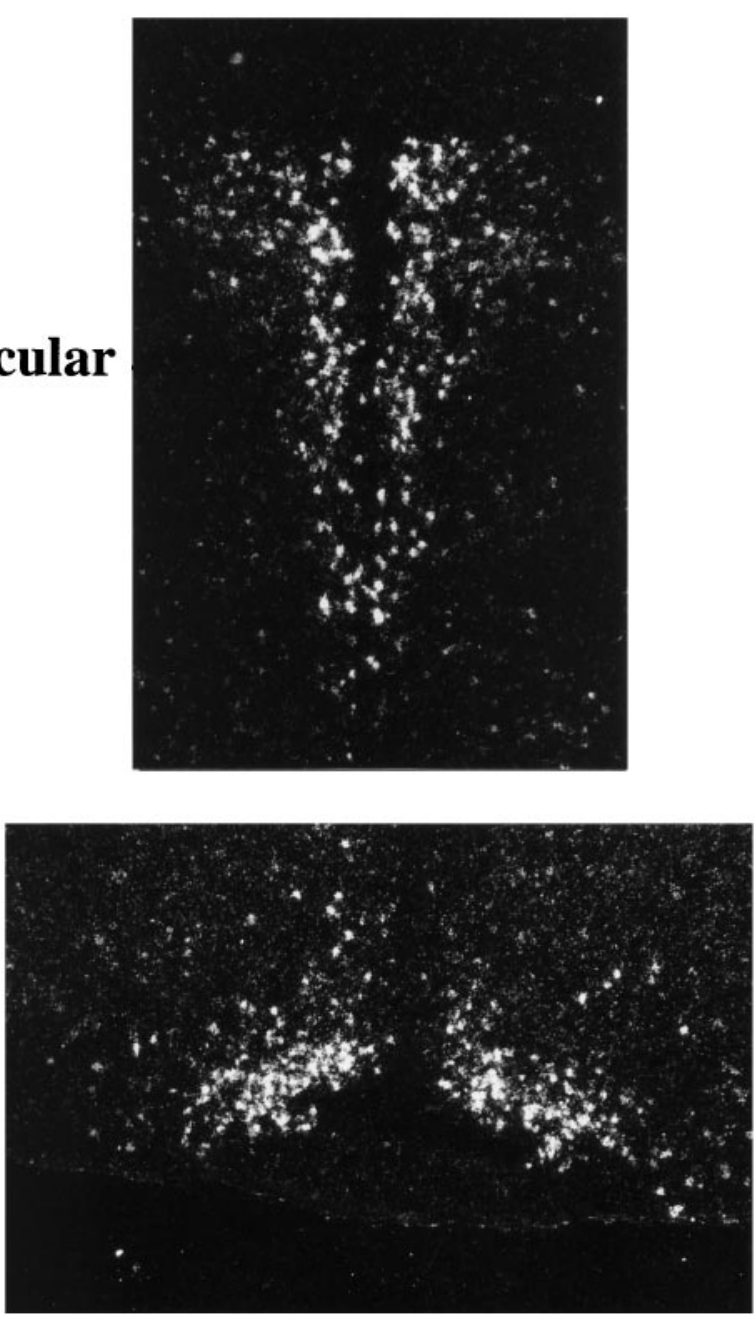

\section{SRIH mRNA}
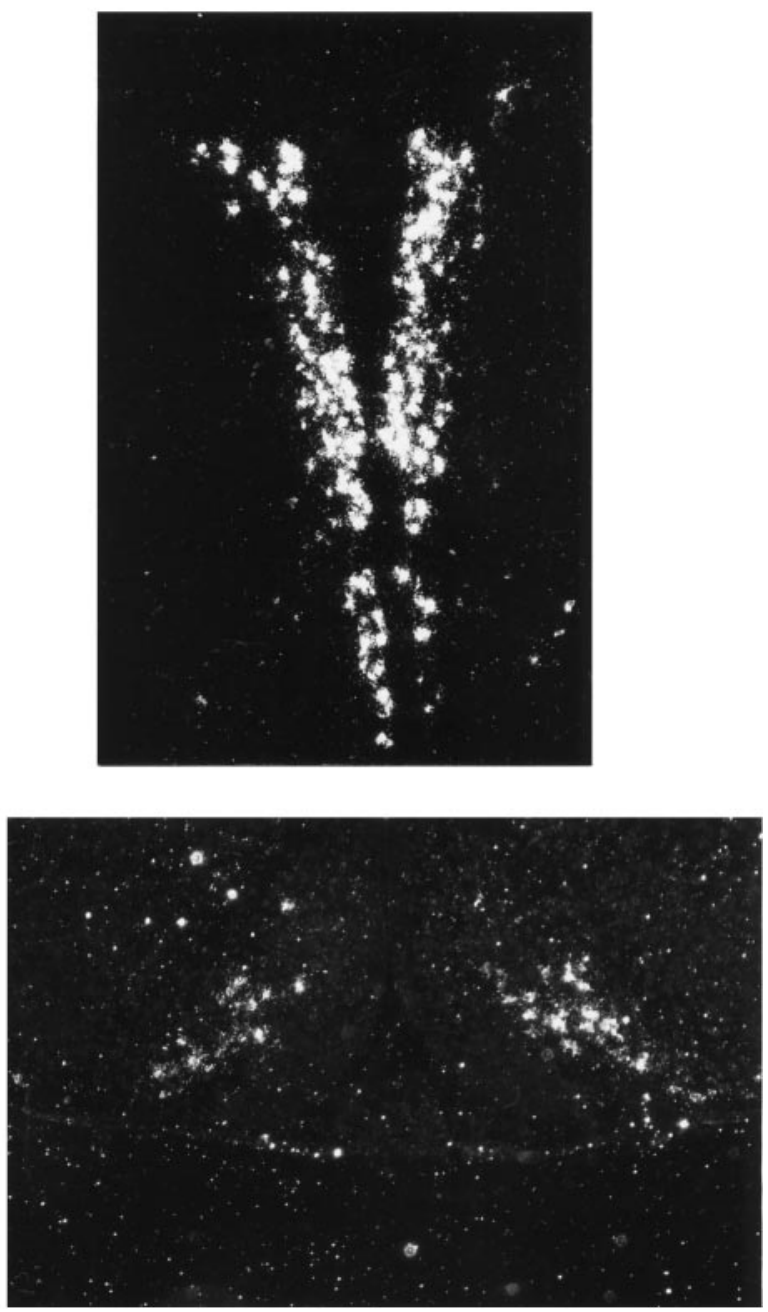

Figure 4. Distribution of (left panels) rGH-R mRNA-, (top right panel) SRIH mRNA-, and (bottom right panel) GHRH mRNA-containing cells in the hypothalamic PeV (top panels) and ARC (bottom panels) nuclei of a control rat (100× magnification).

increases SRIH mRNA concentrations in that nucleus (Bertherat et al., 1993). Taken altogether, these data, as well as parallel effects of the AS treatment on rGH-R mRNA and on SRIH expression, are strongly suggestive that $\mathrm{GH}$ receptors are directly involved in regulating the activity of PeV SRIH neurons. This hypothesis is substantiated further by observations of Burton et al. (1992) showing that GH receptor mRNA colocalizes in $69 \%$ of SRIH mRNA-containing cells within the PeV. Moreover, systemic administration of $\mathrm{GH}$ to hypophysectomized rats induces c-fos gene expression in the PeV, and $60 \%$ of these c-fosexpressing cells coexpress SRIH (Kamegai et al., 1994). Increased GH secretion induced by the rGH-R AS ODN treatment thus is likely to reflect a lower SRIH inhibitory tone on GH release from the pituitary. Such a hypothesis is compatible with the fact that nadir GH values are increased in AS-treated animals in accordance with the model of Tannenbaum and Ling (1984) in which nadir values are controlled essentially by high SRIH plasma levels.

A direct effect on GHRH gene expression could not be documented under our experimental conditions. GHRH neurons in the ARC have not yet been convincingly reported as expressing $\mathrm{GH}$ receptor gene transcripts, in contrast to the majority of arcuate NPY-containing neurons (Chan et al., 1995; Burton et al., 1995). Moreover, in hypophysectomized rats, $60 \mathrm{~min}$ after an intravenous injection of $\mathrm{GH}$, expression of the c-fos gene is increased in arcuate NPY but not in GHRH neurons (Kamegai et al., 1994). Thus, alteration of hypothalamic GH receptors may not directly affect GHRH cells.

A puzzling question raised by these results is that of $\mathrm{GH}$ access to hypothalamic neurons. Although the blood-brain barrier is usually considered impermeable to $\mathrm{GH}$, high levels of plasma $\mathrm{GH}$ found in acromegalic patients are matched by abnormally high GH concentrations in the cerebroventricular fluid (Linfoot et al., 1970). Systemic treatment of GH-deficient patients with recombinant $\mathrm{hGH}$ also results in high GH CSF levels (Johansson et al., 1995). The median eminence is known to lie outside the blood-brain barrier as choroid plexus, on which we and others (Lai et al., 1991) have visualized $\left.{ }^{125} \mathrm{I}\right] \mathrm{hGH}$ binding sites. The relationship between the somatogenic binding sites in the choroid plexus and the hypothalamic sites of rGH-R synthesis remains to be established. At any rate, the choroid plexus binding sites might act as selective transporters from the peripheral circulation to the CSF. Oliver et al. (1977) suggested in an earlier study that high plasma concentrations of pituitary hormone could reach the hypothalamus by retrograde transport from the 


\section{Control rats}

\section{rGH-R mRNA}
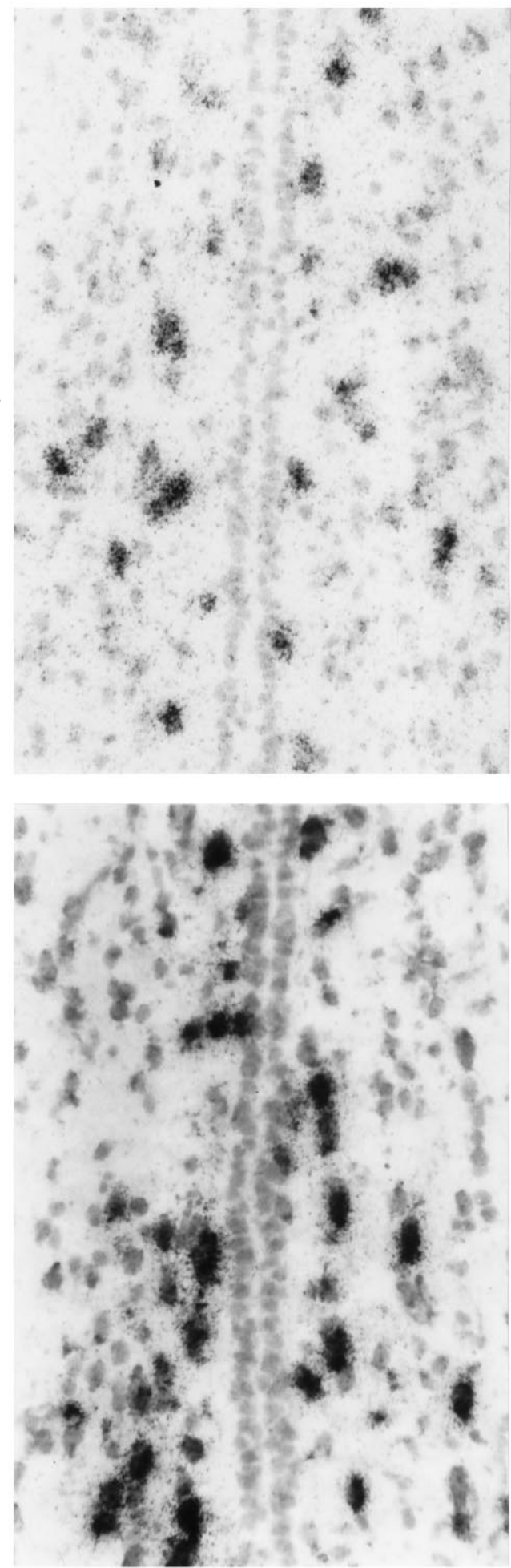

\section{rGH-R AS ODN treated rats}
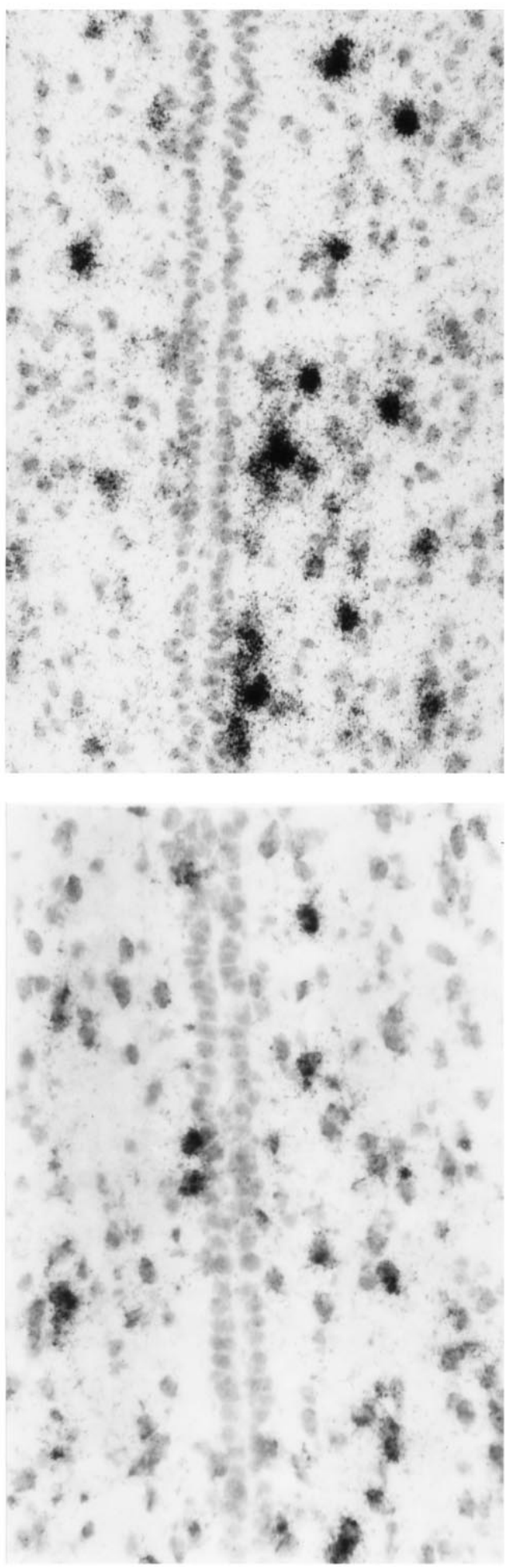

Figure 5. Visualization of the effects of rGH-R AS ODN treatment in the PeV. Autoradiograms are representative of in situ rGH-R (top) and SRIH (bottom) mRNA hybridization signals in the hypothalamic PeV in a control (left) and a $r G H-R A S O D N\left(2.0 \mathrm{nmol}^{\circ} \cdot 0.5 \mu \mathrm{l}^{-1} \cdot \mathrm{hr}^{-1}\right)$-treated (right) rat (300× magnification). 

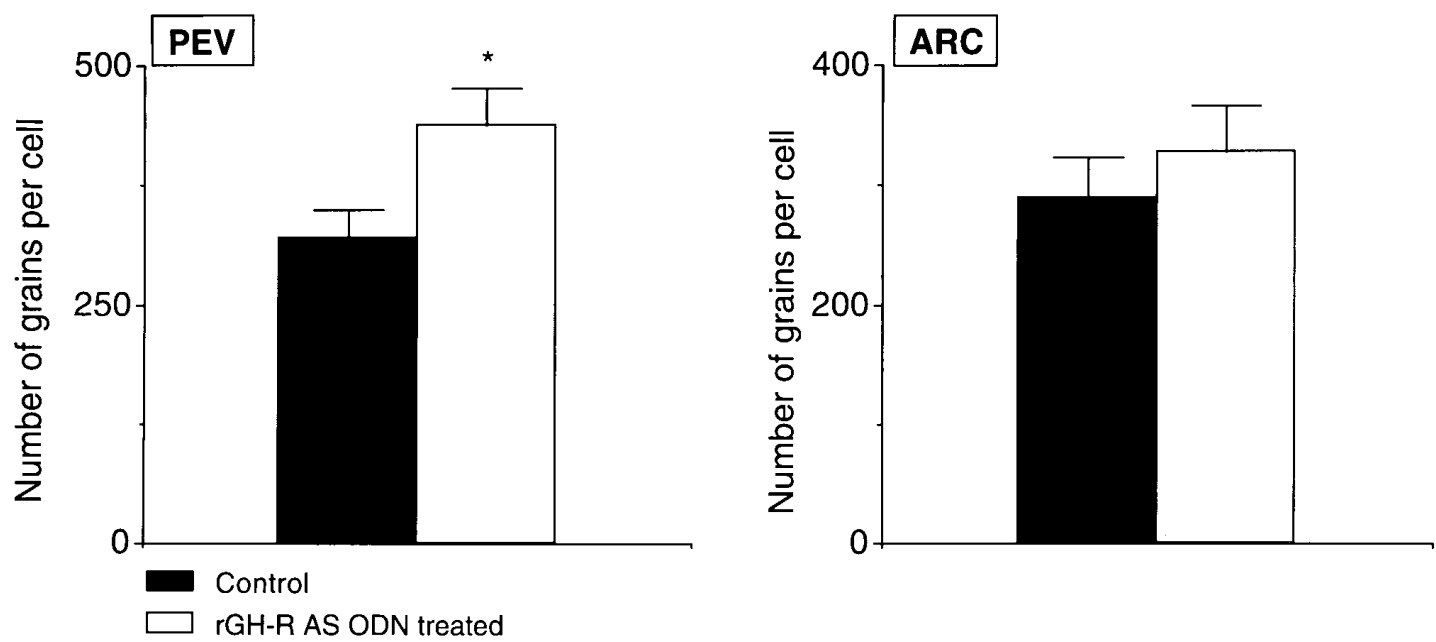

Figure 6. Quantification of the effects of intracerebroventricular infusion of rGH-R AS ODN $\left(2.0 \mathrm{nmol} \cdot 0.5 \mu \mathrm{l}^{-1} \cdot \mathrm{hr}^{-1}\right) \mathrm{on} \mathrm{rGH}^{\mathrm{R}} \mathrm{mRNA}$ levels in the periventricular $(P E V)$ and arcuate $(A R C)$ hypothalamic nuclei. Four sections per region were analyzed in each rat; $n=6$ animals in each group. Data are expressed as mean \pm SEM, and asterisk indicates the level of significance as compared with controls $\left({ }^{*} p<0.05\right)$.

median eminence across stalk portal vessels, but we could not visualize somatogenic binding sites in this neurohemal organ. Alternatively, a central origin of GH acting on the hypothalamus cannot be excluded, because GH-like immunoreactivity is found in various brain structures such as the hypothalamus or the amygdala (Harvey et al., 1993). This GH material is likely to be produced locally, because it is not affected by hypophysectomy (Hojvat et al., 1982).

At any rate, whatever its pituitary or central origin, our experiments are compatible with a working model in which short negative feedback of $\mathrm{GH}$ on its pulsatile secretory pattern
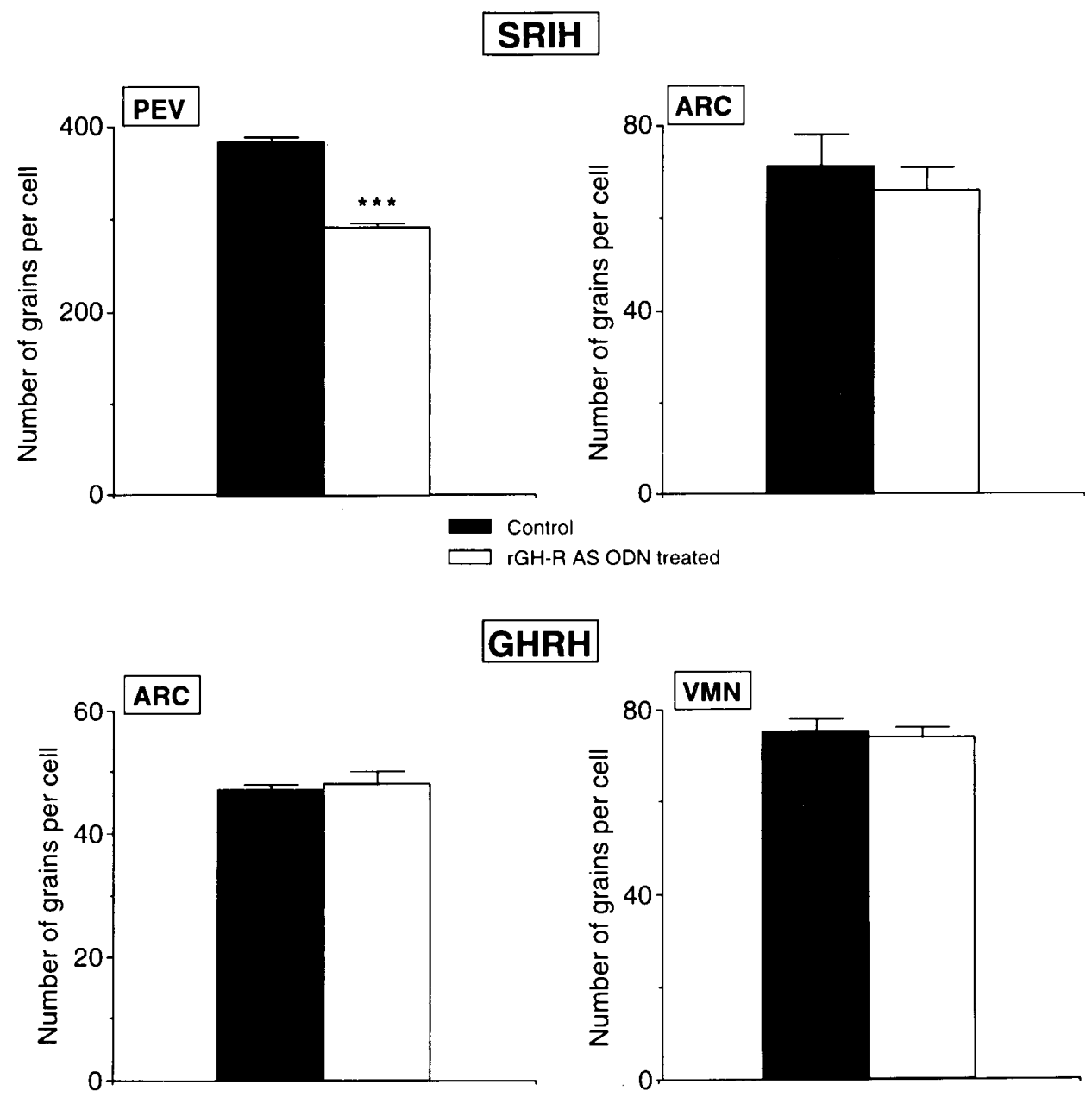

Figure 7. Quantification of the effects of intracerebroventricular infusion of $\mathrm{rGH}-\mathrm{R}$ AS ODN $\left(2.0 \mathrm{nmol} \cdot 0.5 \mu \mathrm{l}^{-1} \cdot \mathrm{hr}^{-1}\right)$ on SRIH and GHRH mRNA levels. Top pan$e l s$, SRIH mRNA levels in the periventricular $(P E V)$ and arcuate $(A R C)$ nuclei. Bottom panels, GHRH mRNA levels in the $\mathrm{ARC}$ and periventromedial nucleus $(V M N)$ region. Eight sections per region were analyzed in each rat; $n=6$ animals in each group. Each column represents the mean, and the vertical bar represents SEM. Asterisks indicate levels of significance with respect to controls $(* * *<0.001)$. 
acts directly on $\mathrm{GH}$ receptors located in the periventricular hypothalamus, thereby triggering the activity of hypophysiotropic somatostatin neurons located in that structure. A direct involvement of GHRH neurons remains to be established.

\section{REFERENCES}

Abe H, Molitch ME, Van Wyk JJ, Underwood IE (1983) Human growth hormone and somatomedin-C suppress the spontaneous release of growth hormone in unanesthetized rats. Endocrinology 113:1319-1324.

Bertherat J, Bluet-Pajot MT, Epelbaum J (1995) Neuroendocrine regulation of growth hormone. Eur J Endocrinol 132:12-24.

Bertherat J, Timsit J, Bluet-Pajot MT, Mercadier JJ, Gourdji D, Kordon C, Epelbaum J (1993) Chronic growth hormone (GH) hypersecretion induces reciprocal and reversible changes in mRNA levels from hypothalamic GH-releasing hormone and somatostatin neurons in the rat. J Clin Invest 91:1783-1791.

Bick T, Youdim MBH, Hochberg Z (1989) Adaptation of liver membrane somatogenic and lactogenic growth hormone $(\mathrm{GH})$ binding to the spontaneous pulsation of $\mathrm{GH}$ secretion in the male rat. Endocrinology 125:1711-1717.

Bisconte JC, Fulcrand J, Marty R (1968) Analyse radioautographique dans le système nerveux central par photométrie et cartographie combinées. C R Soc Biol (Paris) 161:2178-2182.

Bluet-Pajot MT, Durand D, Drouva S, Mounier F, Pressac M, Kordon C (1986) Further evidence that thyrotropin releasing hormone participates in the regulation of growth hormone secretion. Neuroendocrinology 44:70-75.

Bluet-Pajot MT, Schaub C, Nassiet J (1978) Growth hormone response to hypoglycemia under gamma hydroxybutyrate narco analgesia in the rat. Neuroendocrinology 26:141-149.

Burton KA, Kabigting EB, Clifton DK, Steiner RA (1992) Growth hormone receptor messenger ribonucleic acid distribution in the adult male rat brain and its colocalization in hypothalamic somatostatin neurons. Endocrinology 131:958-963.

Burton KA, Kabigting EB, Steiner RA, Clifton DK (1995) Identification of target cells for growth hormone's action in the arcuate nucleus. Am J Physiol 269:E716-E722.

Chan YY, Steiner RA, Clifton DK (1995) Neuropeptide Y-containing neurons in the arcuate nucleus express growth hormone receptor mRNA. 77th Annual Meeting of the Endocrine Society: Washington, D.C.

Chomczynski P, Downs T R, Frohman LA (1988) Feedback regulation of growth hormone $(\mathrm{GH})$-releasing hormone gene expression by $\mathrm{GH}$ in rat hypothalamus. Mol Endocrinol 2:236-241.

Clark RG, Carlsson LMS, Robinson ICAF (1988) Growth hormone (GH) secretion in the conscious rat: negative feedback of GH on its own release. J Endocrinol 119:201-209.

Crumeyrolle-Arias M, Latouche J, Jammes H, Djiane J, Kelly PA, Reymond MJ, Haour F (1993) Prolactin receptors in the rat hypothalamus: autoradiographic localization and characterization. Neuroendocrinology 57:457-466.

Harvey S, Hull KL, Fraser RA (1993) Mini review: growth hormoneneurocrine and neuroendocrine perspectives. Growth Regul 3:161-171.

Hasegawa O, Minami S, Sugihara H, Wakabayashi I (1993) Developmental expression of the growth hormone receptor gene in the rat hypothalamus. Dev Brain Res 74:287-290.

Hojvat S, Baker G, Kirsteins L, Lawrence AM (1982) Growth hormone immunoreactivity in the rodent and primate CNS: distribution, characterization and presence posthypophysectomy. Brain Res 239:543-557.

Johansson JO, Larson G, Andersson M, Elmgren A, Hynsjo L, Lindahl A, Isaksson OGP, Lindstedt S, Bengtsson BA, Lundberg PA (1995) Treatment of growth hormone-deficient adults with recombinant human growth hormone increases the concentration of growth hormone in the cerebrospinal fluid and affects neurotransmitters. Neuroendocrinology 61:57-66.

Kamegai J, Minami S, Sugihara H, Higuchi H, Wakabayashi I (1994) Growth hormone induces expression of the c-fos gene on hypothalamic
neuropeptide-Y and somatostatin neurons in hypophysectomized rats. Endocrinology 135:2765-2771.

Lai Z, Emtner M, Roos P, Nyberg F (1991) Characterization of putative growth hormone receptors in human choroid plexus. Brain Res 546:222-226.

Landgraf R, Gerstberger R, Montkowski Probst JC, Wotjak CT, Holsboer F, Engelmann M (1995) V1 vasopressin receptor antisense oligodeoxynucleotide into septum reduces vasopressin binding, social discrimination abilities and anxiety-related behavior in rats. J Neurosci 15:4250-4258.

Lanzi R, Tannenbaum GS (1992) Time course and mechanism of growth hormone's negative feedback effect on its own spontaneous release. Endocrinology 130:780-788.

Linfoot JA, Garcia JF, Wei W, Fink R, Sarin R, Born JL, Lawrence JH (1970) Human growth hormone levels in the cerebrospinal fluid. J Clin Endocrinol Metab 31:230-232.

Lobie PE, Garcia-Aragon J, Lincoln DT, Barnard R, Wilcox JN, Waters MJ (1993) Localization and ontogeny of growth hormone receptor gene expression in the central nervous system. Dev Brain Res 74:225-233.

Miki N, Ono M, Miyoshi H, Tsushima T, Shizume K (1989) Hypothalamic growth hormone releasing factor (GRF) participates in the negative feedback regulation of growth hormone secretion. Life Sci 44:469-476.

Minami S, Kamegai J, Hasegawa O, Sugihara H, Okada K, Wakabayashi I (1993) Expression of growth hormone receptor gene in rat hypothalamus. J Neuroendocrinol 5:691-696.

Oliver C, Mical RS, Porter JC (1977) Hypothalamic-pituitary vasculature: evidence for retrograde blood flow in the pituitary stalk. Endocrinology 101:598-604.

Paxinos G, Watson C (1986) The rat brain in stereotaxic coordinates. London: Academic.

Rogers KV, Vician L, Steiner RA, Clifton DK (1988) The effect of hypophysectomy and growth hormone administration on preprosomatostatin messenger ribonucleic acid in the periventricular nucleus of the rat hypothalamus. Endocrinology 122:586-591.

Sakai RR, He PF, Yang XD, Ma LY, Guo YF, Reilly JJ, Moga CN, Fluharty SJ (1994) Intracerebroventricular administration of AT (1) receptor antisense oligonucleotides inhibits the behavioral actions of angiotensin II. J Neurochem 62:2053-2056.

Tannenbaum GS (1980) Evidence for autoregulation of growth hormone secretion via the CNS. Endocrinology 107:2117-2120.

Tannenbaum GS, Ling N (1984) The interrelationships of growth hormone $(\mathrm{GH})$-releasing factor and somatostatin in generation of the ultradian rhythm of GH secretion. Endocrinology 115:1952-1957.

Tannenbaum GS, Martin JB (1976) Evidence for an endogenous ultradian rhythm governing growth hormone secretion in the rat. Endocrinology 98:562-570.

Veldhuis JD, Carlson ML, Johnson ML (1987) The pituitary secretes in bursts: appraising the nature of glandular secretory impulses by simultaneous multiple parameter deconvulsion of plasma hormone concentrations. Proc Natl Acad Sci USA 84:7686-7690.

Wahlestedt C, Golanov E, Yamamoto S, Yee F, Ericson H, Yoo H, Inturrisi CE, Reis DJ (1993a) Antisense oligodeoxynucleotides to NMDA-R1 receptor channel protect cortical neurons from excitotoxicity and reduce focal ischaemic infarctions. Nature 363:260-263.

Wahlestedt C, Pich EM, Koob GF, Yee F, Heilig M (1993b) Modulation of anxiety and neuropeptide Y-Y1 receptors by antisense oligodeoxynucleotides. Science 259:528-531.

Willoughby JO, Menadue M, Zeegers P, Wise PH, Oliver JR (1980) Effects of human growth hormone on the secretion of rat growth hormone. J Endocrinol 86:165-169.

Zhou LW, Zhang SP, Qin ZH, Weiss B (1994) In vivo administration of an oligodeoxynucleotide antisense to the D2 dopamine receptor messenger RNA inhibits D2 dopamine receptor-mediated behavior and the expression of D2 dopamine receptors in mouse striatum. J Pharmacol Exp Ther 268:1015-1023. 